\title{
Effect of intrabronchial platelet rich plasma on the exercise-induced pulmonary hemorrhage endoscopic score in thoroughbred racehorses using furosemide: a preliminary study
}

\author{
[Efeito da instilação intrabronquial de plasma rico em plaquetas no escore endoscópico da hemorragia \\ pulmonar induzida por exercício em cavalos Puro-Sangue Inglês de corrida e usuários de furosemida: \\ um estudo preliminar] \\ N. Rebouças Pires ${ }^{1}$, S. Miranda1 , M.F.M. Costa ${ }^{2}$, M.T. Ramos ${ }^{3}$, C. Bernardes ${ }^{1}$, \\ N.X. Alencar ${ }^{1}$, D.A.B. Lessa \\ ${ }^{1}$ Faculdade de Medicina Veterinária - Universidade Federal Fluminense - Niterói, RJ \\ ${ }^{2}$ School of Veterinary Medicine - University of Pennsylvania - Pensilvânia, EUA \\ ${ }^{3}$ Universidade do Grande Rio "Professor José de Souza Herdy" - Duque de Caxias, RJ
}

\begin{abstract}
The high prevalence of exercise-induced pulmonary hemorrhage (EIPH) in athletic horses constitutes to be a challenge to the racing industry and a source of major concern to animal welfare. Both experimental and clinical evidence indicate that the use of autologous platelet-rich plasma (PRP) is a promising effector of repair in a variety of pulmonary conditions. The present study evaluated the effect of intrabronchial instillation of PRP on EIPH endoscopic scores from 37 Thoroughbred racehorses. Inclusion criteria were for animals to be EIPH-positive in, at least, two consecutive post-exercise endoscopic exams and to receive $250 \mathrm{mg}$ of furosemide IV four hours before racing. Animals were randomly assigned into 3 groups: placebo, control, and PRP instillation. All 37 Thoroughbred racehorses included had EIPH endoscopic scores pre- and post- treatment compared by statistical analysis. The bleeding score from the group receiving PRP was significantly lower than in the control and placebo groups. No adverse effects were observed in any animal during or after the experiment. It was possible to conclude that the intrabronchial instillation of autologous PRP was effective in reducing EIPH scores in racehorses receiving furosemide and that this bioproduct can be considered as a promising coadjuvant in controlling EIPH in athletic horses.
\end{abstract}

Keywords: endoscopy, intrabronchial, platelets, racehorses

\section{RESUMO}

A alta prevalência de hemorragia pulmonar induzida por exercício (HPIE) em cavalos atletas é um desafio de longa data para a indústria de corridas, além de figurar como grande preocupação sobre o bem-estar animal. As evidências experimentais e clínicas indicam que o uso do plasma rico em plaquetas $(P R P)$ de fonte autógena é promissor na terapêutica de diversas lesões pulmonares. O presente estudo objetivou avaliar as mudanças após corrida no escore endoscópico de HPIE de 37 cavalos Puro-Sangue Inglês que receberam instilação intrabronquial de PRP autólogo. Os animais selecionados eram HPIEpositivos em, ao menos, dois exames endoscópicos consecutivos e recebiam 250mg de furosemida IV administrado quatro horas antes de cada corrida. Na comparação dos escores endoscópicos pré e póstratamento, verificou-se que o escore de HPIE do grupo tratado com PRP foi significantemente menor que o dos grupos controle e placebo. Nenhum efeito adverso foi observado nos animais durante ou após o experimento. Concluiu-se que a instilação intrabronquial de PRP autólogo foi efetiva na redução do escore de HPIE de cavalos de corrida usuários de furosemida e que este bioproduto pode ser considerado uma alternativa promissora no controle de HPIE em cavalos atletas.

Palavras-chave: endoscopia, intrabronquial, plaquetas, cavalos de corrida

Recebido em 9 de outubro de 2020

Aceito em 24 de fevereiro de 2021

E-mail: nreboucas@infolink.com.br 


\section{INTRODUCTION}

Exercise-induced pulmonary hemorrhage (EIPH) is a highly prevalent condition in racehorses as it is estimated that at least $80 \%$ of these animals will have EIPH at some point during their athletic careers (Birks et al., 2002). The condition is triggered by the physiological response to intense exercise which includes a significant increase in pulmonary ventilation and cardiac output as means to meet oxygen demand. As a result, transmural capillary pressure (TCP) may exceed $75 \mathrm{mmHg}$, causing alveolar vessels to rupture and blood to enter the lower airways (Stack et al., 2014).

In addition to impaired athletic performance, recurrent EIPH may cause debilitating respiratory diseases and lung fibrosis, contributing to the emergence of respiratory infections or even sudden death (Hinchcliff et al., 2009; Crispe et al., 2017). The loop diuretic furosemide reduces the high pulmonary artery pressure caused by exercise, mitigating hemorrhage (Zawadzkas et al., 2006). This drug is currently the only approved medication to control EIPH in racehorses and it is not effective in every case. Therefore, and since EIPH is multifactorial, the use of other therapies in conjunction with furosemide may improve the control of the condition. In this sense, procoagulants, nitric oxide, phosphodiesterase inhibitors, bronchodilators, and controlled water intake have been investigated, albeit with no demonstrable effectiveness. However, it is essential to take into consideration anti-doping regulations adopted in most racing jurisdictions worldwide which ban the use of several drugs before and during competitions (Hinchcliff et al., 2015; WADA, 2021), limiting the therapeutic options for bleeding racehorses in active racing.

This study investigated the effects of instillation of platelet rich plasma (PRP) into the airways of EIPH positive racehorses as a possible, nonpharmacologic adjunct for mitigating EIPH in racehorses. The premise lies on the fact that this bioproduct has been shown to speed up reepithelialization, angiogenesis, cell mitosis, and collagen synthesis, also stimulating neutrophil and macrophage chemotaxis, and deposition of fibroblasts (Anitua et al., 2004; Pavlovic et al., 2016). Furthermore, PRP has been tested as a treatment for inflammatory airway disease (mild asthma), improving respiratory cytology findings after intrabronchial application (Dzyekanski, et al., 2012).

Platelet-rich plasma (PRP) is a biological product obtained by centrifugation of autologous blood and therefore presents minimal risk of crosscontamination, disease transmission or triggering immune reactions (Pavlovic et al., 2016). This blood component contains high concentration of growth factors and is known to promote a faster healing response (Andrade et al., 2016). The principle is to acquire a large number of platelets in a small plasma volume yielding high concentrations of several growth factors released from platelet $\alpha$-granules. Based on the known effects of PRP on several tissues, and the need for novel treatments to reduce or control EIPH, we hypothesized that the intrabronchial instillation of PRP would promote a reduction in the EIPH score of horses medicated with furosemide and that still present bleeding post exercise.

\section{MATERIAL AND METHODS}

This study included 37 thoroughbred racehorses (19 males and 18 females) between 3 and 5 years old, housed in standard stalls ( $3 \mathrm{~m} \mathrm{x} 4 \mathrm{~m}$ ) at the Brazilian Jockey Club, Rio de Janeiro State, Brazil. Informed consent was granted by the owners of all animals included in this study. This research was approved by the Ethics Committee for the Use of Animals in Research (CEUA) of the Universidade Federal Fluminense, Brazil (protocol number 5534070918 ID 000327). The horses were fed commercial feed, alfalfa, and Tifton hay three times a day, with water offered ad libitum. All individuals were vaccinated periodically against rabies, tetanus, Eastern and Western encephalomyelitis, influenza, rhinopneumonitis, and also received routine deworming for intestinal parasite control.

The study was conducted over 24 months, between the years of 2018 and 2020. Inclusion criteria encompassed horses that were regularly participating in races at similar tracks and distances, and were EIPH-positive in, at least, two consecutive endoscopic exams before the experiment. No other pharmacological treatment besides furosemide - 250mg IV administered four hours before race time, in accordance with the racing jurisdiction rules - was used at the 
time of biological sampling. The horses were clinically examined, and a complete blood count, total plasma protein and fibrinogen measurements were obtained to exclude clinical signs of systemic or respiratory illness. All 37 horses were medicated with furosemide and had one initial endoscopic examination (E1) 60 minutes after a race (monitored race $1-\mathrm{R} 1$ ). Visible signs of airway inflammation (i.e., mucosal edema, hyperemia, hyperresponsiveness during endoscopy, and carina edema), and EIPH grade were recorded. Horses were randomly separated into either placebo $(\mathrm{P}, \mathrm{n}=14)$ or treatment $(\mathrm{T}, \mathrm{n}=23)$ groups following the first examination.

Sixty-nine hours after R1 all horses had blood samples collected for laboratory analysis and PRP preparation: $5 \mathrm{~mL}$ of venous blood was collected into a vacuum tube containing EDTA $7.2 \mathrm{mg}$ (Vacutainer ${ }^{\mathrm{TM}}$, Becton Dickinson), and $180 \mathrm{~mL}$ of venous blood was collected into $3.2 \%$ sodium citrate vacuum tubes (Vacutainer ${ }^{\mathrm{TM}}$, Becton Dickinson). The samples in EDTA were used for complete blood count, protein, and fibrinogen measurements, while the samples in sodium citrate were used for PRP preparation following the methodology described by (Miranda et al., 2019).

In summary, blood samples for PRP preparation were rested for 2 hours after collection and then submitted to two consecutive centrifugations for 10 minutes each, at increasing centrifugal forces of $120 \mathrm{x} \mathrm{g}$ and $240 \mathrm{x}$ g, respectively. After each centrifugation, the top $2 / 3$ of the supernatant was discarded. Platelet counts were done manually on a hemocytometer after dilution of a sample aliquot in ammonium oxalate. At 72 hours post $\mathrm{R} 1$, a trans-endoscopic wash (TEW1) was performed, with samples collected for cytology. The parameters obtained from E1 and TEW1 were used as controls $(\mathrm{C})$. Horses received either $10 \mathrm{~mL}$ of $0.9 \%$ saline (group P) or $10 \mathrm{~mL}$ of autologous PRP (group T), instilled transendoscopically immediately after the collection of the wash, $5 \mathrm{~mL}$ into each main bronchus (Dzyekanski, et al., 2012; Barussi et al., 2016).

A second endoscopic examination (E2) was performed 60 minutes after a second monitored race (R2), which took place between 3 and 5 weeks after saline or PRP instillation, depending on each horse's individual training schedule. Blood sampling and TEW with collection of material for cytology were repeated 72 hours after R2 and the results from both collections were compared by the Mann-Whitney U test (GraphPad) with significance set at $95 \%$ (P< 0.05). The summarized experimental timeline can be viewed in Figure 1.

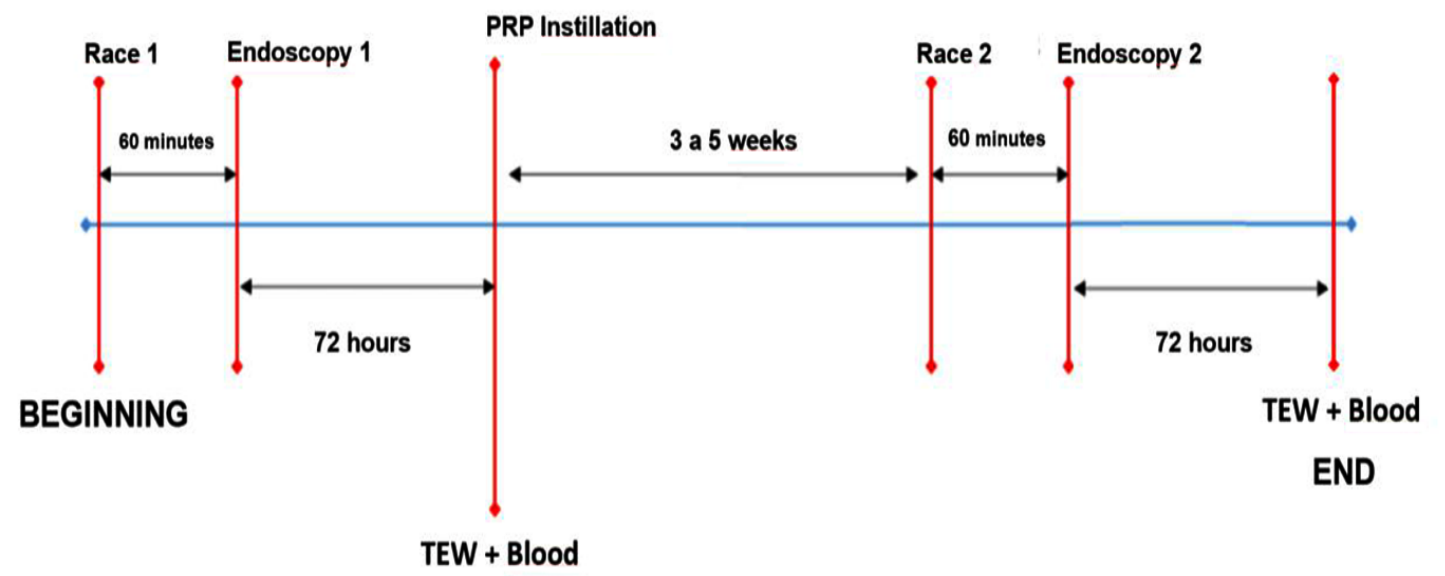

Figure 1. Chronological summary of experimental protocol. Thirty-seven horses presenting EIPH and medicated with furosemide pre-race were evaluated endoscopically 60 minutes after racing (Race 1), treated with either saline or PRP and re-evaluated after a second race (Race 2) after 3 to 5 weeks from treatment. TEW = Trans-endoscopic wash; Blood = point of blood collection for laboratory analysis and PRP preparation. 
All endoscopic examinations were performed by the same veterinarians, using an Olympus CF10L fiberscope, with horses mechanically restrained by a twitch. EIPH was scored by two independent examiners and ranked 0 to 5 (Costa and Thomassian, 2006). Delivery of intrabronchial saline or PRP was accomplished via a delivery catheter (EDC190, Mila Supplies) passed through the working channel of the endoscope. Horses were clinically monitored for 24 hours following the instillations and physical activity was restricted to walking during this period.

\section{RESULTS}

The procedures were well tolerated by all horses, and it was not necessary to sedate the animals. Mild coughing during instillation was the only observed adverse effect, and no other clinical changes were reported in any of the horses during or after intrabronchial administration of PRP or saline solution. The mean platelet count of PRP instilled was $1064 \times 10^{9} / \mathrm{L}$. Table 1 shows individual endoscopic scores before and after intrabronchial instillations, i.e., 60 minutes after R1 and 72 hours after R2, respectively. The bleeding score in Group $\mathrm{T}$ (treated) was significantly lower $(p=0.002)$ than in Group C (control), while no significant differences were found between Group P (placebo) and Group C $(\mathrm{p}=0,999)$, as seen in Figure 2.

\section{DISCUSSION}

It is not uncommon for Thoroughbred racehorses that present EIPH to have persistent bleeding, even when medicated with furosemide (Costa and Thomassian, 2006; Sullivan et al., 2015). In this sense, we hypothesized that the instillation of autologous PRP into the lower airways of horses suffering from persistent bleeding would be beneficial due to the presence of growth factors released from platelets in PRP. The rational for such hypothesis relies on previous works conducted with soft tissue, where optimized healing was achieved by injection of autologous PRP (Filardo et al., 2020). Although most of the work conducted to date evaluates the effects of autologous PRP as a therapeutic option for the musculoskeletal system (Textor, 2014), some veterinarians have putatively utilized PRP to improve respiratory conditions such as equine asthma. There is, however, scant research available to demonstrate this, although there is a published patented methodology for such application of PRP (Gold, 2014).

In this study we have demonstrated that autologous PRP reduces EIPH degree in Thoroughbred racehorses that were still bleeding even with the use of furosemide. This was statistically demonstrated by a significant decrease in the degree of EIPH observed in postrace endoscopies of EIPH positive horses treated with intrabronchial PRP and furosemide, when compared to their control post-race endoscopies (furosemide only) and placebo (furosemide and saline). Furthermore, the intrabronchial instillation of PRP resulted in elimination of visible bleeding post-race (EIPH grade 0) in $26 \%$ of the animals treated, while none of the horses receiving placebo showed this result.

The exact mechanism by which this reduction was achieved is under investigation. From the physiology of platelets, which continuously circulate through blood vessels, including the lungs, a homeostatic effect can be inferred. One possibility is the interaction between damaged blood vessels in the lungs of EIPH positive horses and anti-hemorrhagic substances released by the platelets. While this is a tempting hypothesis, it is unlikely that the volume instilled in this study would have a homeostatic effect. It is even more unlikely that this homeostatic effect would last 3 to 5 weeks, the interval observed between races in this study.

Conversely, activated platelets do have a paracrine effect that could explain why such a small volume could produce a systemic effect and the success observed after intrabronchial administration of $10 \mathrm{~mL}$ of PRP. Indeed, the activated platelets stimulate other thrombocytes by contiguity and increase their area of action. Once activated, platelets act on the integrity of alveolar capillaries by selectively restricting the transfer of water, proteins, and red blood cells out of the vessels, thus contributing to pulmonary vascular repair. Experimental and clinical evidence indicate that thrombocytes are key effectors over injury in a variety of pulmonary disorders and syndromes (Thébaud et al., 2007; Weyrich and Zimmerman, 2013). However, as coagulation profiles were not obtained in this study, this hypothesis cannot be tested at this time. 
Table 1. Individual endoscopic scores of the selected Thoroughbred racehorses before and after intrabronchial instillations

\begin{tabular}{|c|c|c|}
\hline \multirow{2}{*}{$\begin{array}{c}\text { Subjects } \\
\mathrm{n}=37\end{array}$} & \multicolumn{2}{|c|}{ Endoscopic Scores } \\
\hline & Pre-instillation & Post-instillation \\
\hline $\mathrm{C} 1$ & 1 & 3 \\
\hline $\mathrm{C} 2$ & 1 & 2 \\
\hline $\mathrm{C} 3$ & 1 & 3 \\
\hline $\mathrm{C} 4$ & 1 & 2 \\
\hline $\mathrm{C} 5$ & 1 & 2 \\
\hline C6 & 1 & 1 \\
\hline $\mathrm{C} 7$ & 1 & 1 \\
\hline $\mathrm{T} 1$ & 1 & $0 *$ \\
\hline $\mathrm{C} 8$ & 2 & 2 \\
\hline C9 & 2 & 2 \\
\hline $\mathrm{C} 10$ & 2 & 3 \\
\hline $\mathrm{T} 2$ & 2 & $1 *$ \\
\hline $\mathrm{T} 3$ & 2 & $1 *$ \\
\hline T4 & 2 & $0 *$ \\
\hline C11 & 3 & 4 \\
\hline $\mathrm{C} 12$ & 3 & 3 \\
\hline T5 & 3 & $0 *$ \\
\hline T6 & 3 & $2 *$ \\
\hline $\mathrm{T} 7$ & 3 & $2 *$ \\
\hline $\mathrm{T} 8$ & 3 & $0 *$ \\
\hline T9 & 3 & $0^{*}$ \\
\hline T10 & 3 & 3 \\
\hline $\mathrm{T} 11$ & 3 & $1 *$ \\
\hline $\mathrm{T} 12$ & 3 & $1 *$ \\
\hline T13 & 3 & 3 \\
\hline $\mathrm{T} 14$ & 3 & $1 *$ \\
\hline $\mathrm{T} 15$ & 3 & $1 *$ \\
\hline C13 & 4 & 4 \\
\hline T16 & 4 & $3^{*}$ \\
\hline $\mathrm{T} 17$ & 4 & $2 *$ \\
\hline T18 & 4 & $2 *$ \\
\hline T19 & 4 & $0^{*}$ \\
\hline T20 & 4 & 4 \\
\hline $\mathrm{T} 21$ & 4 & $1 *$ \\
\hline C14 & 5 & $3 *$ \\
\hline $\mathrm{T} 22$ & 5 & 5 \\
\hline $\mathrm{T} 23$ & 5 & $3 *$ \\
\hline
\end{tabular}

Note: Subjects identified by the letter $\mathrm{C}$ form the control group and received $0.9 \%$ saline solution, while those identified by the letter T were treated with PRP. *horses that showed reduction in EIPH severity score after the intrabronchial instillation procedure.

Another more plausible explanation is the effect of the release of growth factors, abundant in the $\alpha$-granules of platelets (Marx, 2004; Pavlovic et al., 2016), The $\alpha$-granules contain soluble and membrane bound proteins, which are bioactive and heterogeneous regarding function, are involved in clotting, inflammation, cell growth, cell adhesion, host defense (Coppinger et al., 2004), and act specifically on repair or remodeling of pulmonary, bronchial, and alveolar blood vessels (Weyrich and Zimmerman, 2013). In mice, PRP has stimulated lung vascularization, overall improving pulmonary efficiency and function. Researchers have concluded that PRP is potentially a beneficial therapy in the regeneration of damaged lung tissue in humans (Mammoto et al., 2016).

There are no studies evaluating the direct effect of growth factors concentration and lung cell proliferation in horses, although there is evidence that EIPH leads to frequent, severe, and extensive remodeling of the lung vasculature and angiogenesis (Hinchcliff et al., 2015). Vascular lesions observed in EIPH include collagen accumulation in the adventitia and, in some vessels, smooth muscle hyperplasia. In the most affected areas, there is significant reduction in vessel luminal diameter, contributing to the perpetuation of venous hypertension, which in turn enhances capillary rupture and extravasation of blood into alveolar spaces (Stack et al., 2014). Vessel remodeling, fibrosis and hemosiderin impregnation follow a caudo-dorsal distribution much like the gross lesions observed in EIPH (Williams et al., 2013).

It is possible that the substances present in PRP exert modulation over collagen deposition in lung vessels, promoting remodeling and favoring malleability, therefore reducing the deleterious effects of increased venous blood pressure. It is known that epithelial cells and endothelial receptors crosstalk during lung development and repair, so it is plausible that molecules, such as vascular endothelial growth factor (VEGF), introduced via the administration of PRP, modulate lung plasticity during EIPH (Voelkel et al., 2006; Thébaud et al., 2007, 2019).

Inability to measure the direct interactions between PRP and growth factor receptors is one of the obvious limitations of this clinical study. Ideally, the effects of the intrabronchial administration of PRP should also be evaluated in EIPH-positive horses that are not under furosemide treatment to assess its effectiveness separately from the actions of the diuretic. This was not possible under the conditions of the 
present study as the rules of the Brazilian Racing Code (Brasil, 2012) dictate that EIPH positive horses over 3 years of age can be administered furosemide 4 hours prior to racing in order to minimize bleeding. Since that is the case, owners and trainers of EIPH positive horses are very reluctant to race EIPH horses without the medication.

In the interest of minimizing interfering variables, parameters such as distance raced, and track surface were similar between R1 and R2. The interval between races (3-5 weeks) did not exceed 60 days, which would be considered a break in training (Crispe et al., 2019), in accordance with the 2015 Consensus Statement of the American College of Veterinary Internal Medicine (Hinchcliff et al., 2015). No other factors were controlled as these were active, privately owned career racehorses. The protocol of administration of PRP recommended from our results does not infringe the rules of racing, as the horses are treated at least 3 weeks before their race day. This is an advantage, and it was very well received among the trainers whose horses participated in the study. As per normal racing jurisdiction procedures (Brasil, 2012), horses are regularly submitted to post-race antidoping testing, and in the case of this study, $46 \%$ of the horses were submitted to drug testing. All tests were negative, emphasizing the fact that PRP is an autologous non-pharmacological product that does not interfere with anti-doping policies, and showing the possible therapeutic role of PRP in controlling EIPH in athletic horses.

The mean thrombocyte count of the PRP used in our study was $1064 \times 10^{9}$ platelets/L, which is within the range described in the literature. There is no consensus regarding the minimum number of platelets required for PRP to be effective, although a concentration three times greater than the initial platelet count needs to be achieved for PRP to be considered as such (Anitua et al., 2004). Some authors suggest that thrombocytes concentration should range from 800 to $1200 \mathrm{x}$ $10^{9}$ platelets/L (Weibrich et al., 2004), while others consider that $1000 \times 10^{9}$ platelets/L may represent a therapeutic dose of PRP (Marx, 2004).

EIPH is considered by some to be phenomenon triggered by physiologic adaptations to high intensity exercise, including an increase in pulmonary vascular pressure, which can be mitigated by furosemide administration prior to exercise (Sullivan et al., 2015). Although it has been demonstrated that the administration of this loop diuretic before racing reduces the EIPH score in a significant number of horses (Hinchcliff et al., 2009; Sullivan et al., 2015), this drug is not always effective (Costa and Thomassian, 2006; Sullivan et al., 2015). This is likely due to co-factors that contribute to bleeding, such as capillary fragility and tissue damage that could have happened in previous occasions (Hinchcliff et al., 2015; Silva et al., 2017).

In this sense, PRP is a promising adjuvant treatment to control EIPH, likely due to its antihemorrhagic and regenerative properties, and its modulatory action from $\alpha$-granule growth factors (Pavlovic et al., 2016). Furthermore, the intrabronchial use of PRP, in our study, demonstrated to be a safe procedure as no adverse effects were reported in the animals during or after the treatment.

\section{CONCLUSION}

Intrabronchial administration of PRP was effective in reducing EIPH scores in furosemide medicated racehorses. Thus, this autologous blood product therapy stands as a promising adjuvant in the control of EIPH in athletic horses. Other studies comparing PRP without furosemide, as well as the combination of PRP and furosemide used in this research would be needed to better understand the mode of action of PRP and interactions of these therapeutic agents. The positive effects observed after bronchial instillation of PRP on EIPH scores suggest that a combination of PRP and furosemide is better than furosemide alone for mitigating - and in $26 \%$ of the cases diminishing EIPH. 


\section{REFERENCES}

ANDRADE，M.G.M.G.; RODRIGUES，G.M.; LIMA, D.P. et al. Use of plasma rich in platelets of rabbits with few leukocytes and erythrocytes to consolidate bones. Arq. Bras. Med. Vet. Zootec., v.68, p.276-282, 2016.

ANITUA, E.; ANDIA, I.; ARDANZA, B. et al. Autologous platelets as a source of proteins for healing and tissue regeneration. Thromb. Haemost., v.91, p.4-15, 2004.

BARUSSI, F.C.M., BASTOS, F.Z, LEITE, L.M.B. et al. Intratracheal therapy with autologous bone marrow-derived mononuclear cells reduces airway inflammation in horses with recurrent airway obstruction. Respir. Physiol. Neurobiol., v.232, p.35-42, 2016.

BIRKS, E.K.; SHULER, K.M.; SOMA, L.R. et al. EIPH: postrace endoscopic evaluation of Standardbreds and Thoroughbreds. Equine Vet. J. Suppl., v.34, p.375-378, 2002.

BRASIL. Ministério da Agricultura, Pecuária e Abastecimento: Código Nacional de Corridas. 2012. Disponível em: http://pesquisa.in.gov.br/ imprensa/jsp/visualiza/index.jsp?data=21/03/201 $2 \&$ jornal $=1 \&$ pagina $=15 \&$ totalArquivos $=168$. Acessado em: 20 set. 2020.

COPPINGER, J.A.; CAGNEY, G.; TOOMEY, S. et al. Characterization of the proteins released from activated platelets leads to localization of novel platelet proteins in human atherosclerotic lesions. Blood, v.103, p.2096-2104, 2004.

COSTA, M.F.M.; THOMASSIAN, A. Evaluation of race distance, track surface and season of the year on exercise-induced pulmonary haemorrhage in flat racing Thoroughbreds in Brazil. Equine Vet. J. Suppl., v.36, p.487-489, 2006.

CRISPE, E.J., LESTER, G.D., SECOMBES, C.J. et al. Exercise-induced pulmonary haemorrhage affects raceday performance in thoroughbred horses. Vet. Rec., v.180, p.1-2, 2017.

CRISPE, E.J.; SLOCOMBE, C.J.; PERERA, D.I. et al. Exercise-induced pulmonary haemorrhage in Thoroughbred racehorses: a longitudinal study. Equine Vet. J., v.51, p.45-51, 2019.
DZYEKANSKI, B.; ROCHA, D.C.C.; LOPES, A.C.A.M. et. al. Intrabronchial instillation of platelet-rich plasma in equines with inflammatory airway disease - preliminary report. Estud. Biol., v.34, p.31-35, 2012.

EQUINE anti-doping \& controlled medication regulations. Fédération Équestre Internationale, 2021. Disponível em: Available in: https://inside.fei.org/content/anti-doping-rules. Accessed in: 3 Feb. 2021.

FILARDO, G.; PREVITALI, D.; NAPOLI, F. et al. PRP Injections for the treatment of knee osteoarthritis: A meta-analysis of randomized controlled trials. Cartilage, p.1-12, 2020.

GOLD, R. Methods and compositions for treating respiratory conditions using platelet enriched plasma. U.S. Patent n. 8,753,882, 10 Dec, 2011, 17 Jun. 2014.

HINCHCLIFF, K.W.; COUETIL, L.L.; KNIGHT, P.K. et al. Exercise induced pulmonary hemorrhage in horses: American College of Veterinary Internal Medicine consensus statement. J. Vet. Intern. Med., v.29, p.743-758, 2015.

HINCHCLIFF, K.W.; MORLEY, P.S.; GUTHRIE, A.J. Efficacy of furosemide for prevention of exercise-induced pulmonary hemorrhage in Thoroughbred racehorses. J. Am. Vet. Med. Assoc., v.235, p.76-82, 2009.

MAMMOTO, T.; CHEN, Z.; JIANG, A. Acceleration of lung regeneration by platelet-rich plasma extract through the low-density lipoprotein leceptor-related protein 5-Tie2 pathway. Am. J. Respir. Cell Mol. Biol., v.54, p.103-113, 2016.

MARX, R.E. Platelet-rich plasma: evidence to support its use. J. Oral Maxillofac. Surg., v.62, p.489-496, 2004.

MIRANDA, S.; COSTA, M.F.M.; REBOUÇAS, N. Protocols for preparation of platelet rich plasma (PRP) in Quarter Horses. Pesqui. Vet. Bras. v.39, p.614-621, 2019.

PAVLOVIC, V.; CIRIC, M.; JOVANOVIC, V. et al. Platelet rich plasma: a short overview of certain bioactive components. Open Med., v.11, p.242-247, 2016. 
SILVA, K.M.; OTAKA, J.N.P.; GONÇALVES, C.A.P. et al. Association between exerciseinduced pulmonary hemorrhage and inflammatory airway disease in polo ponies. $J$. Equine Sci., v.28, p.55-59, 2017.

STACK, A.; DERKSEN, J.F.; WILLIAMS, J.K. et al. Lung region and racing affect mechanical properties of equine pulmonary microvasculature. $J$. Appl. Physiol., v.117, p.370-376, 2014.

SULLIVAN, S.L.; WHITTEM, T.; MORLEY, P.S. et al. A systematic review and meta-analysis of the efficacy of furosemide for exerciseinduced pulmonary haemorrhage in Thoroughbred and Standardbred racehorses. Equine Vet. J., v.47, p.341-349, 2015.

TEXTOR, J. Platelet-rich plasma (PRP) as a therapeutic agent: platelet biology, growth factors and a review of the literature. In: LANA, J.F.S.D.; SANTANA, M.H.A.; BELANGERO, W.D.; LUZO, A.C.M. (Eds.). Platelet-rich plasma. Berlin: Springer Berlin Heidelberg, 2014. p.61-94.

THÉBAUD, B.; ABMAN, S.H. Bronchopulmonary dysplasia: where have all the vessels gone? Roles of angiogenic growth factors in chronic lung disease. Am. J. Respir. Crit. Care Med., v.175, p.978-985, 2007.
THÉBAUD, B.; GOSS, K.N.; LAUGHON, M. et al. Bronchopulmonary dysplasia. Nat. Rev. Dis. Primers, v.5, p.1-23, 2019.

VOELKEL, N.F.; VANDIVIER, R.W.; TUDER, R.M. Vascular endothelial growth factor in the lung. Am. J. Physiol. Lung Cell Mol. Physiol., v.290, p.L209-L221, 2006.

WADA: World anti-doping agency code. Revised in 2021. URL: www.wada-ama.org

WEIBRICH, G.; HANSEN, T.; KLEIS, W. et. al. Effect of platelet concentration in platelet-rich plasma on peri-implant bone regeneration. Bone, v.34, p.665-671, 2004.

WEYRICH, A.S.; ZIMMERMAN, G.A. Platelets in Lung Biology. Annu. Rev. Physiol., v.75, p.569-591, 2013.

WILLIAMS, K.J.; DERSEN, F.J.; FEIJTERRUPP, H; PANNIRSELVAM, R.R.; STEEL, C.M. ROBINSON N.E. Regional pulmonary veno-occlusion: a newly identified lesion of equine exercise-induced pulmonary hemorrhage. Veterinary Pathology, v. 45, p.316-326, 2008.

ZAWADZKAS, X.A.; SIDES, R.H.; BAYLY, W.M. Is improved high speed performance following frusemide administration due to diuresis-induced weight loss or reduced severity of exercise-induced pulmonary haemorrhage? Equine Vet. J. Suppl., v.36, p.291-293, 2006. 